\title{
Quelques aspects de l'évolution de l'artisanat du textile à Alep (Syrie)
}

Jocelyne Cornand

\section{(2) OpenEdition}

1 Journals

Édition électronique

URL : https://journals.openedition.org/tc/895

DOI : $10.4000 /$ tc.895

ISSN : 1952-420X

Éditeur

Éditions de l'EHESS

\section{Édition imprimée}

Date de publication : 1 février 1987

ISSN : 0248-6016

\section{Référence électronique}

Jocelyne Cornand, «Quelques aspects de l'évolution de l'artisanat du textile à Alep (Syrie)»,

Techniques \& Culture [En ligne], 8 | 1987, mis en ligne le 23 janvier 2006, consulté le 29 septembre

2022. URL : http://journals.openedition.org/tc/895 ; DOI : https://doi.org/10.4000/tc.895

Ce document a été généré automatiquement le 29 septembre 2022.

Tous droits réservés 
Quelques aspects de l'évolution de l'artisanat du textile à Alep (Syrie)

Jocelyne Cornand 